\title{
PENGGUNAAN TEKNOLOGI INFORMASI SEBAGAI MEDIA PEMBELAJARAN DALAM PEMBELAJARAN MATEMATIKA SMA
}

\author{
Mukhni, ${ }^{1, a}$ Mirna $^{1, b}$, Khairani $^{1, c}$ \\ ${ }^{1}$ Jurusan Matematika, FMIPA, Universitas Negeri Padang, \\ Jl. Prof. Dr. Hamka, Padang 25171 \\ e-mail: amukhniajoo@yahoo.co.id, bmirna_ujang@yahoo.com, \\ 'khairani@fmipa.unp.ac.id
}

\begin{abstract}
Mathematics is well known as abstract subject. Mathematics learning needs media in order to bring its concepts to real life, so it feels more concrete. However, some of teachers do not use media in mathematics learning, especially information technology. The aim of this study was to describe whether mathematics teachers use technology information as media learning in classroom. Type of study was descriptive research with qualitative approach. Instrument was questionnaire with Likert scale. Samples of study were 35 mathematics teachers of senior high school in Padang Pariaman. The result shows that $82 \%$ mathematics teachers in Padang Pariaman do not use technology information as media learning in classroom.
\end{abstract}

Keywords : information technology, mathematics, media learning

\begin{abstract}
Abstrak
Matematika merupakan mata pelajaran yang abstrak. Pembelajaran matematika membutuhkan media agar konsep matematika dapat teraplikasikan dalam kehidupan sehari-hari sehingga menjadi lebih konkret bagi peserta didik. Namun, beberapa guru matematika tidak menggunakan media dalam pembelajaran, terutama media yang berbasiskan teknologi informasi. Tujuan penelitian ini adalah untuk mengetahui apakah guru matematika menggunakan perangkat teknologi informasi sebagai media pembelajaran di kelas. Penelitian ini merupakan penelitian deskriptif dengan pendekatan kualitatif. Instrumen yang digunakan adalah angket dengan skala Likert. Sampel penelitian adalah 35 guru matematika SMA di kabupaten Padang Pariaman. Hasil penelitian menunjukkan bahwa $82 \%$ guru matematika di Padang Pariaman belum memanfaatkan teknologi informasi sebagai media pembelajaran matematika di kelas.
\end{abstract}

Kata kunci : matematika, media pembelajaran, teknologi informasi 


\section{PENDAHULUAN}

Matematika merupakan pelajaran wajib yang dipelajari di setiap jenjang pendidikan dasar dan menengah di Indonesia, mulai dari pendidikan usia dini (PAUD), sekolah dasar (SD), sekolah menengah pertama (SMP) dan sekolah menengah atas (SMA). Bahkan, matematika juga dipelajarai hingga jenjang pendidikan tinggi di berbagai universitas dan institut. Hal tersebut dikarenakan matematika memiliki peranan yang penting dalam kehidupan manusia. Berbagai temuan teknologi berdasarkan perhitungan matematika. Matematika juga banyak digunakan dalam bidang keilmuan lain, seperti sains, teknik mesin, geografi, psikologi dan ilmu sosial lainnya [1]. Aplikasi matematika yang sangat luas dan pada berbagai bidang yang berbeda, menjadikan matenatika ini sering disebut sebagai bahasa ilmu pengetahuan.

Namun, pentingnya matematika tersebut tidak menjadi dasar bagi peserta didik untuk menggemari materi matematika. Sering ditemukan bahwa peserta didik tidak menyukai matematika dan bahkan tidak jarang peserta didik mengalami kecemasan terhadap matematika [2]. Hal ini dapat dikarenakan sifat dari konsep matematika yang cenderung abstrak. Sifat abstrak tersebut menyulitkan peserta didik memahami materi matematika. Mereka hanya menghapal prosedur penyelesaian soal tanpa memahami konsep matematika [1] [3]. Selain itu, pembelajaran matematika di banyak sekolah masih menerapkan teacher centered learning [4]. Peserta didik menjadi kurang aktif dalam menggali pengetahuan. Mengingat hal tersebut, pemerintah Indonesia membuat kebijakan dengan menerapkan kurikulum 2013 berfokus dengan pendekatan saintifik. Pada kurikulum tersebut, guru dimintakan untuk memberikan pembelajaran di kelas dengan disertakan media pembelajaran. Penggunaan media dalam pembelajaran matematika dilakukan untuk membawa konsep matematika yang abstrak tersebut menjadi lebih konkret sehingga 
peserta didik dapat memahami pemanfaatannya dalam kehidupan sehari-hari.

Pemanfaatan media dalam pembelajaran telah terbukti dapat meningkatkan kemampuan bekerjasama dan komunikasi peserta didik [5][6]. Selain itu, penggunaan media dalam pembelajaran juga dapat meningkatkan self-efficacy dan motivasi peserta didik [7][8].

Berbagai manfaat media dalam pembelajaran tersebutlah yang menjadi dasar pemerintah untuk mengeluarkan Permendikbud tentang penggunaan media dalam pembelajaran, yaitu Permendikbud Nomor 22 Tahun 2016 tentang Pemanfaatan TIK untuk meningkatkan efisiensi dan efektivitas pembelajaran [9]. Berdasarkan Permendikbud tersebut, guru diharapkan untuk menjalankan pembelajaran di kelas dengan menggunakan media dan fasiltas TIK, baik penggunaan komputer, laptop, infokus, software matematika dan lain sebagainya. Langkah tersebut dimaksudkan agar guru siap untuk menghadapi pembelajaran masa depan yang berorientasi pada revolusi industri 4.0.

Guru sebagai agen pembelajaran (learning agent) harus memiliki empat kompetensi sebagaimana yang dimaksud dalam Pasal 8 Undang-Undang Republik Indonesia nomor 14 tahun 2005 meliputi kompetensi pedagogik, kompetensi kepribadian, kompetensi sosial, dan kompetensi profesional yang diperoleh melalui pendidikan profesi [10]. Kompetensi pedagogik merupakan kemampuan guru dalam mengelola pembelajaran. Kompetensi kepribadian merupakan kemampuan guru dalam berperilaku. Kompetensi sosial merupakan kemampuan guru sebagai bagian dari masyarakat. Sedangkan kompetensi profesional merupakan kemampuan guru dalam menguasai pengetahuan bidang ilmu, teknologi, dan/atau seni yang sekurang-kurang meliputi penguasaan materi pelajaran secara luas dan mendalam sesuai standar isi program satuan pendidikan, mata pelajaran, dan/atau kelompok mata pelajaran yang diampunya, dan konsep-konsep dan metode disiplin keilmuan, teknologi, atau seni yang relevan yang secara konseptual menaungi atau koheren dengan program satuan pendidikan, mata pelajaran, dan/atau kelompok mata 
pelajaran yang diampu. Keempat kompetensi tersebut di atas bersifat holistik dan integratif dalam kinerja guru.

Adapun kemampuan guru dalam menggunakan media pembelajaran termasuk dalam kompetensi profesional. Kuantitas pengunaan media pembelajaran, terutama media yang berbasiskan teknologi informasi di kelas, menjadi salah satu indikator yang menunjukkan keprofesionalan guru dalam mengajar.

\section{METODE PENELITIAN}

Penelitian ini bertujuan untuk mengetahui apakah guru matematika menggunakan media pembelajaran berbasis teknologi informasi pada pembelajaran matematika di kelas. Subjek penelitian ini ada 35 guru matematika SMA di kabupaten Padang Pariaman, Sumatera Barat. Penelitian ini merupakan penelitian deskriptif. Instrumen yang digunakan adalah angket yang terdiri atas 12 pernyataan skala Likert dengan yang terdiri atas 6 pernyataan positif dan 6 pernyataan negatif serta 3 pertanyaan terbuka. Pernyataan pada angket dibuat berdasarkan 6 aspek, yaitu persepsi guru tentang pengaruh penggunaan media terhadap kualitas pembelajaran, kuantitas penggunaan media di kelas, wawasan tentang media pembelajaran berbasi teknologi informasi, wawasan tentang media pembelajaran manipulatif, fasilitas media pembelajaran yang ada di sekolah serta dampak penggunaan media terhadap siswa di kelas. Adapun pertanyaan terbuka yang disertakan dalam angket, yaitu tentang definisi media pembelajaran, tujuan dan fungsi media pembelajaran serta pentingnya penggunaan media pada setiap kegiatan pembelajaran. Data dari angket tersebut dianalisis dengan menggunakan pendekatan kualitatif. 


\section{HASIL DAN PEMBAHASAN}

Data yang diperoleh dari angket dianalisa secara kualitatif. Adapun angket ini menggunakan skala Likert yang dengan pilihan responnya berupa angka dari skala 1-11. Adapaun skala 1 untuk menunjukkan respon sangat tidak setuju (strongly disagree) sedangkan skala 11 menunjukkan respon sangat setuju (strongly agree). Responden dimintai untuk melingkari angka yang menjadi pilihan mereka. Adapun angka 1 hingga 5 menunjukkan respon tidak setuju terhadap pernyataan sedangkan angka 7 hingga 11 menunjukkan respon setuju dengan pernyataan. Adapun responden yang melingkari angka 6 tidak termasuk dalam respon setuju maupun tidak setuju (netral). Hasil dari analisa angket yang menggunakan skala Likert, ditunjukkan pada tabel di bawah ini.

Tabel 1. Hasil Analisa Angket

\begin{tabular}{lcc}
\hline Aspek & $\begin{array}{c}\text { Persentase } \\
\text { Kesetujuan } \\
\text { Terhadap } \\
\text { Pernyataan } \\
\text { Potisif }\end{array}$ & $\begin{array}{c}\text { Persentase } \\
\text { Ketidaksetujuan } \\
\text { Terhadap } \\
\text { Pernyataan } \\
\text { Negatif }\end{array}$ \\
\hline $\begin{array}{l}\text { persepsi guru tentang pengaruh penggunaan } \\
\text { media terhadap kualitas pembelajaran }\end{array}$ & 94.29 & 85.29 \\
$\begin{array}{l}\text { kuantitas penggunaan media di kelas } \\
\text { wawasan tentang media pembelajaran } \\
\text { berbasis teknologi informasi }\end{array}$ & 42.86 & 60 \\
$\begin{array}{l}\text { wawasan tentang media pembelajaran } \\
\text { manipulatif } \\
\text { fasilitas media pembelajaran yang ada di } \\
\text { sekolah } \\
\text { dampak penggunaan media terhadap siswa } \\
\text { di kelas }\end{array}$ & 85.67 & 52.94 \\
\hline
\end{tabular}

Tabel 1 menunjukkan bahwa guru memiliki persepsi yang baik mengenai pentingnya penggunaan media dalam pembelajaran matematika. Hal tersebut terlihat dari persentase kesetujuan guru terhadap pernyataan positif, yaitu sebesar 94.29\% dan ketidaksetujuan guru terhadap pernyataan negatif, yaitu sebesar 85.29\%. Persepsi guru tentang pentingnya penggunaan media dalam pembelajaran juga 
terlihat dari jawaban yang diberikan guru terhadap pertanyaan terbuka yang disertakan dalam angket. Pertanyaan yang diberikan adalah "Jelaskan tujuan dan fungsi media dalam pembelajaran?". Semua guru (100\%) memberikan jawaban bahwa media berguna untuk memudahkan guru menyampaikan materi pelajaran dan memudahkan siswa memahami materi yang diajarkan di kelas.

Namun, pada tabel 1 juga terlihat bahwa kuantitas penggunaan media yang dilakukan guru di kelas masih rendah. Hal tersebut tampak dari respon kesetujuan guru terhadap pernyataan positif angket, sebesar $42.86 \%$ dan ketidaksetujuan terhadap pernyataan negatif sebesar 60\%. Jawaban yang diberikan guru terhadap pertanyaan terbuka yang diberikan dalam angket juga menunjukkan bahwa penggunaan media dalam pembelajaran masih rendah. Pertanyaan yang diberikan adalah "Menurut Anda, apakah setiap mengajar perlu media pembelajaran?". Analisa angket menunjukkan bahwa 16 guru (45.71\%) menjawab perlunya media pembelajaran digunakan pada setiap pembelajaran di kelas, namun 19 guru (54.29\%) memberikan jawaban bahwa pengunaan media tidak perlu dilakukan pada setiap pembelajaran, tergantung materi yang diajarkan. Ada guru yang menjawab bahwa ia tidak tahu media apa yang cocok digunakan untuk menyajikan materi tertentu sehingga pembelajaran yang dilakukan tanpa media. Terlihat bahwa guru belum memiliki pengetahuan yang memadai tentang media pembelajaran.

Rendahnya penggunaan media dalam pembelajaran matematika juga dikarenakan karena tidak adanya fasilitas tersebut di sekolah. Analisa angket menunjukkan bahwa sekolah dari 29 guru (82.86\%) telah menyediakan infokus walaupun tidak semua kelas memiliki infokus tersebut. Tetapi, ada 6 guru (17.14\%) yang menyatakan bahwa sekolah mereka tidak tersedia infokus. Dari 6 guru tersebut, 3 guru menjawab bahwa mereka hanya menggunakan alat peraga dalam pembelajaran sedangkan 3 guru yang lain memberikan jawaban bahwa mereka tidak menggunakan alat peraga dalam pembelajaran. Adapun dari 29 guru yang sekolahnya menyediakan infokus, hanya 5 guru 
yang menggunakan fasilitas infokus tersebut untuk menampilkan media dari software Powerpoint, Geogebra dan Frezzi dalam pembelajaran di kelas. Sedangkan guru yang lain tidak melakukan hal yang sama karena mereka tidak memiliki kompetensi dalam penggunaan media teknologi informasi. Rendahnya kompetensi guru dalam pengetahuan mengenai teknologi informasi juga tampak dari hasil analisa angket pada Tabel 1 . Tabel tersebut menunjukkan bahwa $36.67 \%$ guru memberikan respon setuju dengan pernyataan positif mengenai wawasan mengenai media teknologi informasi dan 52.94\% guru menyatakan ketidaksetujuan mereka terhadap pernyataan negatifnya.

Rendahnya pengetahuan guru mengenai wawasan media teknologi informasi menjadi penyebab guru memiliki persepsi bahwa tidak semua materi pelajaran dapat diajarkan dengan menggunakan media. Mereka berpandangan bahwa media pembelajaran hanya dapat digunakan di kelas pada materi-materi tertentu saja, seperti materi ruang dimensi tiga (geometri) sedangkan materi matematika yang lain seperti aljabar dan kalkulus tidak ada media pembelajaran. Hal tersebut dikarenakan guru terbiasa menggunakan alat peraga manipulatif, seperti kerangka kubus dan lain sebagainya. Guru tidak memiliki pengetahuan bahwa materi aljabar dan kalkulus dapat difasilitasi dengan software komputer, seperti Geogebra dan Macromedia Flash. Apabila guru memiliki kompetensi dalam penggunaan software komputer maka guru dapat merancang media pembelajaran terkait materi ajar matematika, baik materi geometri, aljabar, kalkulus, statistika dan lain sebagainya. Dengan demikian, maka guru akan memahami bahwa semua materi matematika dapat dirancang media pembelajarannya yang sesuai, baik menggunakan media pembelajaran manipulatif (seperti alat peraga) maupun media pembelajaran berbasis teknologi informasi (seperti Powerpoint, Geogebra, dan lain sebagainya). Dengan adanya pemahaman tersebut, maka persepsi guru yang menyatakan bahwa tidak semua materi matematika dapat diajarkan dengan menggunakan media, akan 


\section{Hipotenusa}

Journal of Research Mathematics Education

menghilang dan pelaksanaan pembelajaran di kelas akan sesuai dengan arahan kurikulum 2013 dan sesuai dengan Permendikbud nomor 22 tahun 2016. Apabila hal tersebut terjadi, maka tujuan pembelajaran matematika akan tercapai.

\section{KESIMPULAN DAN SARAN}

Hasil penelitian ini menunjukkan bahwa guru memiliki persepsi yang baik mengenai fungsi dan tujuan media pembelajaran. Namun, penggunaan media pembelajaran yang dilakukan di kelas dalam pembelajaran matematika masih rendah. Hal tersebut dikarenakan guru masih memiliki anggapan bahwa tidak semua materi matematika bisa diajarkan dengan menggunakan media. Hasil angket juga menunjukkan bahwa banyak guru yang belum memiliki kompetensi dalam menggunakan software/program komputer, sehingga banyak guru yang hanya menggunakan media pembelajaran manipulatif di dalam kelas.

Berdasarkan temuan tersebut, sebaiknya guru meningkatkan kemampuan penggunakan software komputer yang nantinya dapat diaplikasikan sebagai media pembelajaran. Peningkatan kemampuan tersebut dapat dilakukan dengan mengikuti pelatihan/workshop atau belajar mandiri. Hal tersebut harus dilakukan oleh guru agar memiliki kemampuan yang dibutuhkan untuk menghadapi masa revolusi industri 4.0. 


\section{DAFTAR PUSTAKA}

[1] Khairani, Mukhni \& Aini F., Q. (2018). Problem analysis of calculus learning in higher education Advances in Social Science, Education and Humanities Research (ASSEHR) vol $285 \mathrm{p}$ 75-78.

[2] Khairani. (2016). Perbandingan Kemampuan Penalaran Aljabar dan Math Anxiety Antara Siswa yang Belajar Melalui Model $7 E$ Learning Cycle dan Siswa yang Belajar Melalui Model Concept Attainment. Bandung : Universitas Pendidikan Indonesia, Tesis, Tidak Dipublikasikan.

[3] Mirna. (2018). Error analysis of students in mathematics department to learn plane geometry. IOP Conf. Series: Journal of Physics: Conf. Series 335(2018) 012116

[4] Khairani, Amry, Z. \& Rosalina. (2018). Upaya meningkatkan kemampuan berpikir kritis siswa kelas X melalui pembelajaran kooperatif tipe numbered head together. Jurnal Eksakta Pendidikan, vol 2, number 1 pp. 85-92.

[5] Neo, M. \& Neo, T-K. (2009) Engaging students in multimedia mediated contructivist learning-students perception. Journal Educational Technology \& Society, 12(2), pp. 254-266.

[6] Karahan E, Canbazoglu-Bilici, S. \& Unal, A. (2015). Integration of media design processes in science, technology, engineering and mathematics (STEM) education. Eurasian Journal of Educational Research 60 pp. 221-240.

[7] Chun-Ming, H., Iwen, H. \& Gwo-Jen, H. (2014) Effect of digital game-based learning on students' self-efficacy, motivation, anxiety and achievement in learning mathematics. Journal of Computer and Education, vol. 1(2) pp. 151-166.

[8] Neo, M. \& Neo, T-K. (2009). Engaging students in multimedia mediated contructivist learning-students perception. Journal Educational Technology \& Society, 12(2), pp. 254-266.

[9] Permendikbud Nomor 22 Tahun 2016 tentang Pemanfaatan TIK.

[10] Undang-Undang RI Nomor 14 Tahun 2005 tentang Guru dan Dosen.. 